\title{
Epidemiology of Rheumatoid Arthritis (RA) in rural and urban areas of Poland - 2008-2012
}

\author{
Petre Iltchev ${ }^{3}$, Andrzej Śliwczyński ${ }^{1,2}$, Tomasz Czeleko², Aleksandra Sierocka ${ }^{4}$, \\ Franciszek Szatko7, Michał Marczak ${ }^{3}$ \\ ${ }^{1}$ Public Health Department, Health Sciences Faculty, Medical University, Łódź, Poland \\ ${ }^{2}$ National Health Fund (NFZ), Warsaw, Poland \\ ${ }^{3}$ Health Care Policy Department, Medical University, Łódź, Poland \\ ${ }^{4}$ K. Jonscher Hospital, Łódź, Poland \\ ${ }^{5}$ Military Medical Institute, Warsaw, Poland \\ ${ }^{6}$ Emergency Medicine and Disaster Medicine Institute, Medical University, Łódź, Poland \\ ${ }^{7}$ Hygiene and Epidemiology Department, Medical University, Łódź, Poland
} Małgorzata Tłustochowicz ${ }^{5}$, Witold Tłustochowicz ${ }^{5}$, Dariusz Timler ${ }^{6}$, Melania Brzozowska ${ }^{2}$,

\begin{abstract}
Iltchev P, Śliwczyński A, Czeleko T, Sierocka A, Tłustochowicz M, Tłustochowicz W, Timler D, Brzozowska M, Szatko F, Marczak M. Epidemiology of Rheumatoid Arthritis (RA) in rural and urban areas of Poland - 2008-2012. Ann Agric Environ Med. 2016; 23(2): 350-356. doi: $10.5604 / 12321966.1203904$
\end{abstract}

\begin{abstract}
Objective. The aim of this study is to investigate the morbidity rate due to Rheumatoid Arthritis (RA) in the Polish population during 2008-2012, calculated per 1,000 inhabitants, and taking into account the differences between provincess, area of residence (urban or rural) and gender.

Materials and method. From the NFZ IT systems, PESEL number information was obtained for all 17 types of services contracted in 2008-2012, for patients whose main diagnosis in the report was the ICD-10 disease code: M05.X - seropositive rheumatoid arthritis, or M06.X - other rheumatoid arthritis. The number of patients, gender and age were calculated based on the PESEL number provided in the statistical reports of the patient with the analysed ICD-10 diagnosis. Urban and rural cases were compared using commune zip codes. The basis for classifying the patient as a member of an urban or rural population was the Zip Code of the declared place of residence. Urban and rural areas are classified based on administrative criteria provided by the Central Statistical Office: the National Official Register of Territorial Division of the Country (TERYT). Results. During the studied period the number of RA patients increased from 173,844-230,892. In urban areas, the most patients were recorded in the Śląskie Province, the least in Lubuskie Province. Patients from rural areas were approx. $1 / 3^{\text {rd }}$ of the total population of patients in Poland. In rural areas, the most patients were recorded in the Mazowieckie Province, the least in Lubuskie Province. The morbidity rate in cities was 5.08 in 2008 and increased to 8.14 in 2012 in rural areas, respectively, it was 3.74 and increased to 3.98. Regardless of the place of residence the women fell ill 3.5 times more frequently. The lowest morbidity rate, both in rural and urban areas, was recorded in the Lubuskie Province, the largest in Świętokrzyskie Province. The the most probable explanation of the highest morbidity rate in the latter province is a worse access to a rheumatologist: in this province there is the lowest number of inhabitants per one employed rheumatologist. Conclusion. In Poland, the number of RA sufferers is increasing, which is probably a result of increasing life expectancy. In Poland, also exists a differences in morbidity between urban and rural inhabitants. Differences may also derive from undiagnosed cases of the disease.
\end{abstract}

\section{Key words}

rheumatoid arthritis, morbidity, epidemiology, urban, rural

\section{INTRODUCTION}

Rheumatoid arthritis (RA) is a chronic autoimmune inflammatory disease leading to the destruction of joint structure and tissue surrounding the joints and degrading their function. The disease is frequently accompanied by pain, inflammation and morning stiffness of joints. The multi-year process may lead to infirmity, disability and even premature death [1]. Studies indicate that the longevity of RA patients compared to the general population is 3 years shorter in the case of women, and 7 years shorter in the case of men [2]. The aetiology of the disease remains unknown.

Address for correspondence: Andrzej Śliwczyński, Prescription Management Department, NFZ Headquarters, Grójecka 186, 02-390 Warsaw, Poland

E-mail: andrzej.sliwczynski@nfz.gov.pl

Received: 29 July 2013; accepted: 09 July 2014
RA is a part of a group of diseases for which early diagnosis for indicating the optimum treatment method is difficult. It requires specialised diagnostic testing and the use of a treatment that is not only effective, but more importantly, immediate. According to published data, in the very early stage of the disease joint destruction may occur [3], and with $10 \%$ of patients erosion occur within 3 months from the first symptoms ( $70 \%$ of patients within 1 year).

The diagnosis is established pursuant to the criteria established by ACR in 1987 and new criteria published in 2010, prepared by the European League Against Rheumatism (EULAR) and the American College of Rheumatology (ACR) $[4,5]$. These criteria include symptoms (small joint inflammation), presence of a rheumatoid factor and/or antiCCP antibodies, and the presence of acute phase indicators (accelerated $\mathrm{OB}$ and increased concentration of $\mathrm{C}$-Reactive Protein (CRP), duration of disease of 6 weeks or more, as 
well as the presence of subcutaneous nodules and radiologic changes. New guidelines allow earlier diagnosis of the disease and more rapid healing, and thus, guarantees better results of the therapy [6].

Unfortunately, despite the achievements in the treatment of RA, its efficacy sometimes leaves something to be desired. Low effectiveness of the drugs used, together with reduced access to more expensive treatment methods, means that the high costs are borne not only by the patient, but also the whole of society (work absences and loss of productivity, necessity of caring for a disabled patient). Available publications indicate that during only one year in the USA there occurred the hospitalisation of approx. 250,000 patients which resulted in $9,000,000$ visits by physicians [7]. At the same time, the costs of the drugs amounted to approx. $66 \%$ of all expenses, their amount depending mainly on the type of therapy used (e.g. biological). The costs of hospitalisation and specialised ambulatory care were $17 \%$ and $16 \%$, respectively respectively [8].

In Poland, there is no data concerning RA morbidity and the distribution of patients in various provinces or urban and rural areas of Poland, nor are there any publications indicating that a difference exists in the number of patients between urban and rural area inhabitants in the period from the first symptoms to diagnosing the disease, and then commencing treatment using drugs that modify the course of the disease. To-date, the documentation of general practitioners and family practitioners is kept in paper form; the first symptoms of the patient's disease (including those related to RA) are not kept in databases at the regional and central level. In order to calculate the time difference between the first symptoms and commencing the treatment, access to the medical documentation of family practitioners or a questionnaire survey of a representative sample of patients are required. One possible solution is to analyse the age of the patient filling a prescription for the refunding of medicinal products for RA treatment for the first time.

Analysis of data divided into urban / rural RA morbidity indicators is rarely conducted $[9,10]$, and the first such study concerning the difference in services for RA resulting from the place of residence in the UK was conducted by Basu and Steven and published in 2009 [11]. In Poland, access to the data of reports provided by health service providers to the Provincial Branches (Regional Branches) of the National Health Fund (NFZ) enabled analysis of the population of RA patients in 2008-2012, which show in particular the morbidity indicators per 1,000 inhabitants:

1) divided into urban and rural areas;

2) taking into account the type of commune, divided by gender;

3) taking into account the type of commune, divided by province.

\section{MATERIALS AND METHOD}

Health services in Poland are financed by the National Health Fund (NFZ), pursuant to the Act [12] and the Regulation of the Minister of Health resulting thereof [13]. Treatment of rheumatoid diseases is performed within the framework of a health services provision contract. The rules of organisation, financing and settling of the services are set out for the service providers in the Regulations of the President of the
NFZ [14]. The ability to provide first diagnosis and therapy of rheumatoid diseases exists in each of the 17 types of contracted services. The condition for receiving from the patients prescriptions for reimbursing medicines used for the treatment of RA is the confirmation of their diagnosis by a rheumatologist. For this reason, the presented study includes only patients with the diagnosis of RA confirmed by a rheumatologist. Data related to a patient's age, gender and place of residence were selected and extracted from the NFZ IT system. Creating the morbidity database [15] for rheumatoid diseases from the NFZ IT systems PESEL number, information was taken for all 17 types of services contracted in 2008-2012, for patients whose main diagnosis in the report was the ICD-10 disease code: M05.X - seropositive rheumatoid arthritis, or M06.X - other rheumatoid arthritis. The number of patients, gender and age were calculated based on the unique ID number (PESEL) provided in the statistical reports of patients with the analysed ICD-10 diagnosis. The analysis presented the lack of data on two levels:

1) an incorrectly provided (non-existent) PESEL number, in which case the data was marked ' $N$ ';

2) incorrectly provided or not provided address of domicile, in which case the data was marked 'BD'. This situation occurs when the therapy is provided for a homeless person or a foreigner.

The number of incorrect data did not exceed $0.2 \%$ and had no impact on statistical significance (in 2008 it amounted to $0.17 \%$; in $2009-0.14 \%$; in $2010-0.10 \%$; in $2011-0.08 \%$; in $2012-0.05 \%)$. The data was collected from the databases using SQL tools with a filter in accordance with the accepted scope of ICD-10 diagnoses, and analysis was conducted using Excel and R version 2.15.3 [16] tools. Data about the number of population in each province were downloaded from the Central Statistical Office website.

The basis for classifying a patient as a member of a urban or rural population was the Zip Code of the declared place of residence. Urban and rural areas are classified based on administrative criteria provided by the Central Statistical Office: The Nomenclature of Territorial Units for Statistical Purposes (NTS) and National Official Register of Territorial Division of the Country (TERYT) [17].

\section{RESULTS}

In 2008-2012, patients with RA in Poland were identified from the NFZ IT system data, which was depersonalized, aggregated and exported to an Excel file. The following attributes and dimensions were specified: place of residence (urban or rural area), gender and province (Tab. 1). The provinces with the greatest number of patients were marked in green, and those with the smallest number of patients in yellow.

The number of patients reported to the NFZ in Poland in 2008 amounted to a little over 170, 000, and in 2012 to 230,000 . In urban areas, the most patients were recorded in the Śląskie, Mazowieckie and Dolnośląskie Provinces, the least in the Lubuskie, Opolskie and Podlaskie Provinces. In rural areas, the most patients were recorded in the Mazowieckie, Wielkopolskie and Małopolskie Provinces, the least in Lubuskie, Opolskie and Zachodniopomorskie Provinces. Patients from rural areas accounted for approx. $1 / 3^{\text {rd }}$ of the total population of patients in Poland. The 
Table 1. Population of patients with diagnosed rheumatoid arthritis, divided by areas and into provinces - 2008-2012

\begin{tabular}{|c|c|c|c|c|c|}
\hline $\begin{array}{l}\text { Population - region/ } \\
\text { provinces }\end{array}$ & 2008 & 2009 & 2010 & 2011 & 2012 \\
\hline Urban & 118372 & 130637 & 132285 & 149262 & 151846 \\
\hline DOLNOŚLĄSKIE & 7957 & 8158 & 8959 & 12425 & 13048 \\
\hline KUJAWSKO-POMORSKIE & 8028 & 8846 & 8876 & 9637 & 10203 \\
\hline LUBELSKIE & 5332 & 5735 & 5553 & 5506 & 5297 \\
\hline LUBUSKIE & 2246 & 2325 & 2548 & 3600 & 3663 \\
\hline ŁÓDZKIE & 8657 & 10535 & 10240 & 10400 & 10822 \\
\hline MAŁOPOLSKIE & 6159 & 6312 & 6407 & 7951 & 8268 \\
\hline MAZOWIECKIE & 18276 & 21343 & 21065 & 21011 & 21102 \\
\hline OPOLSKIE & 2482 & 2372 & 2472 & 2930 & 3159 \\
\hline PODKARPACKIE & 3952 & 3971 & 4084 & 5155 & 5701 \\
\hline PODLASKIE & 2812 & 3397 & 3406 & 3477 & 3937 \\
\hline POMORSKIE & 9323 & 10015 & 10669 & 13178 & 12770 \\
\hline ŚLĄSKIE & 15539 & 16055 & 17335 & 22287 & 21654 \\
\hline ŚWIĘTOKRZYSKIE & 4645 & 4941 & 4973 & 6114 & 6089 \\
\hline WARMIŃSKO-MAZURSKIE & 5901 & 6208 & 5513 & 5584 & 5803 \\
\hline WIELKOPOLSKIE & 11057 & 13345 & 13186 & 12638 & 12768 \\
\hline ZACHODNIOPOMORSKIE & 6006 & 7079 & 6999 & 7369 & 7562 \\
\hline Rural & 55472 & 63319 & 64873 & 75937 & 79046 \\
\hline DOLNOŚLĄSKIE & 2235 & 2203 & 2752 & 4162 & 4451 \\
\hline KUJAWSKO-POMORSKIE & 3905 & 4254 & 4272 & 4473 & 4848 \\
\hline LUBELSKIE & 4996 & 5846 & 5802 & 5865 & 5663 \\
\hline LUBUSKIE & 739 & 757 & 882 & 1448 & 1487 \\
\hline ŁÓDZKIE & 3399 & 4551 & 4608 & 4925 & 5123 \\
\hline MAŁOPOLSKIE & 4211 & 4442 & 4817 & 6573 & 6815 \\
\hline MAZOWIECKIE & 8500 & 9937 & 9909 & 10279 & 10650 \\
\hline OPOLSKIE & 1575 & 1524 & 1713 & 2249 & 2443 \\
\hline PODKARPACKIE & 4253 & 4275 & 4382 & 6087 & 6944 \\
\hline PODLASKIE & 1473 & 1837 & 1930 & 1972 & 2180 \\
\hline POMORSKIE & 2741 & 2913 & 3304 & 4449 & 4659 \\
\hline ŚLĄSKIE & 3111 & 3239 & 3663 & 5581 & 5441 \\
\hline ŚWIĘTOKRZYSKIE & 3771 & 4570 & 4564 & 5209 & 5093 \\
\hline WARMIŃSKO-MAZURSKIE & 2616 & 2897 & 2524 & 2597 & 2796 \\
\hline WIELKOPOLSKIE & 6222 & 7956 & 7632 & 7852 & 7982 \\
\hline ZACHODNIOPOMORSKIE & 1725 & 2118 & 2119 & 2216 & 2471 \\
\hline Total & 173844 & 193956 & 197158 & 225199 & 230892 \\
\hline
\end{tabular}

morbidity rate in cities was 5.08 in 2008 , which increased to 8.14 in 2012 in rural areas - 3.74 and increased to 3.98 , respectively (Tab. 2). In urban areas, it was more than twice as many than in rural areas (with the exception of 2008). In 2012, compared to 2008, the morbidity indicator for Poland increased by 1.4 case per 1,000 inhabitants. This applied to urban areas where the number increased by over 3 cases per 1,000 , whereas in rural areas the morbidity stayed at the same level.
Table 2. Morbidity indicator in Poland per 1,000 inhabitants in 2008-2012, divided into urban and rural areas

\begin{tabular}{lccccc}
\hline Type of commune & 2008 & 2009 & 2010 & 2011 & 2012 \\
\hline Urban communes & 5.08 & 7.09 & 7.17 & 8.00 & 8.14 \\
\hline Rural communes & 3.74 & 3.21 & 3.29 & 3.82 & 3.98 \\
\hline Poland & $\mathbf{4 . 5 7}$ & $\mathbf{5 . 0 9}$ & $\mathbf{5 . 1 7}$ & $\mathbf{5 . 8 5}$ & $\mathbf{5 . 9 9}$ \\
\hline
\end{tabular}

Among urban dwellers, the morbidity indicator for women was approx. 3.5 times higher than for men. A similar tendency was noted in rural communes (a difference factor of approximately three) (Tab. 3).

Table 3. Morbidity indicator per 1,000 inhabitants, taking into account type of commune, divided by gender, in 2008-2012 in Poland

\begin{tabular}{llllll}
\hline Type of commune & 2008 & 2009 & 2010 & 2011 & 2012 \\
\hline Urban communes & $\mathbf{5 . 0 8}$ & $\mathbf{5 . 6 1}$ & $\mathbf{5 . 6 8}$ & $\mathbf{6 . 3 8}$ & $\mathbf{6 . 4 9}$ \\
\hline Women & 7.71 & 8.50 & 8.55 & 9.62 & 9.81 \\
\hline Men & 2.16 & 2.40 & 2.49 & 2.79 & 2.82 \\
\hline Rural communes & $\mathbf{3 . 7 4}$ & $\mathbf{4 . 2 5}$ & $\mathbf{4 . 3 5}$ & $\mathbf{5 . 0 1}$ & $\mathbf{5 . 2 2}$ \\
\hline Women & 5.72 & 6.47 & 6.59 & 7.61 & 7.89 \\
\hline Men & 1.73 & 2.02 & 2.44 & 2.40 & 2.53 \\
\hline
\end{tabular}

Table 4 lists the RA morbidity indicators divided by provinces. The highest indicator, both for rural (from 5.41 in 2008 to 7.25 in 2012) and urban (from 8.06 in 2008 to 10.58 in 2012) communes was present in the Świętokrzyskie Province. The lowest morbidity indicator for urban areas was noted in the Lubuskie (3.49 in 2008 and 3.62 in 2009), Małopolskie (3.81 in 2008 and 3.88 in 2009) and Podlaskie (3.96 in 2008) Provinces. For rural areas, the lowest value within the analysed period was present in Lubuskie Province (2.02 in 2008) and Małopolskie (2.52 in 2008) rovince.

Differences in rural communes in 2008 amounted to from 2.02 (Lubuskie Province) to 5.41 (Świętokrzyskie Commune). In 2012, these values were slightly lower and amounted to from 3.97 (Lubuskie) to 7.25 (Ŝwiętokrzyskie).

By analysing the average value of morbidity indicator within the tested period, a clear difference can be observed between urban and rural areas (Fig. 1).

In 2008-2012, the highest average value of morbidity indicator for both areas was present in the Świętokrzyskie, Pomorskie and Kujawsko-Pomorskie Provinces, the lowest average value of the indicator was present in Małopolskie, Lubuskie and Podlaskie Provinces (Tab.1, Fig. 1).

For each province in each year an indicator reflecting morbidity differences between urban and rural areas was calculated. Figure 2 represents the changes of this indicator during 2008-2012 for regions where the differences between urban and rural areas have grown most rapidly, and for regions where there was the largest advance in decreasing the difference. 
Table 4. Morbidity indicator per 1,000 inhabitants, taking into account the type of commune, divided by communes in 2008-2012 in Poland

\begin{tabular}{|c|c|c|c|c|c|}
\hline Type of commune & 2008 & 2009 & 2010 & 2011 & 2012 \\
\hline Urban communes & 5.08 & 5.61 & 5.68 & 6.38 & 6.49 \\
\hline DOLNOŚLĄSKIE & 3.92 & 4.04 & 4.44 & 6.11 & 6.41 \\
\hline KUJAWSKO-POMORSKIE & 6.37 & 7.04 & 7.07 & 7.60 & 8.05 \\
\hline LUBELSKIE & 5.30 & 5.71 & 5.53 & 5.46 & 5.25 \\
\hline LUBUSKIE & 3.49 & 3.62 & 3.97 & 5.55 & 5.65 \\
\hline ŁÓDZKIE & 5.28 & 6.46 & 6.30 & 6.44 & 6.70 \\
\hline MAŁOPOLSKIE & 3.81 & 3.88 & 3.94 & 4.84 & 5.04 \\
\hline MAZOWIECKIE & 5.43 & 6.32 & 6.23 & 6.19 & 6.22 \\
\hline OPOLSKIE & 4.58 & 4.40 & 4.59 & 5.52 & 5.96 \\
\hline PODKARPACKIE & 4.60 & 4.60 & 4.69 & 5.85 & 6.47 \\
\hline PODLASKIE & 3.96 & 4.75 & 4.74 & 4.80 & 5.44 \\
\hline POMORSKIE & 6.32 & 6.78 & 7.22 & 8.79 & 8.52 \\
\hline ŚLA̧SKIE & 4.27 & 4.43 & 4.79 & 6.20 & 6.02 \\
\hline ŚWIĘTOKRZYSKIE & 8.06 & 8.61 & 8.69 & 10.62 & 10.58 \\
\hline WARMIŃSKO-MAZURSKIE & 6.90 & 7.27 & 6.46 & 6.47 & 6.73 \\
\hline WIELKOPOLSKIE & 5.77 & 6.98 & 6.90 & 6.57 & 6.64 \\
\hline ZACHODNIOPOMORSKIE & 5.16 & 6.09 & 6.00 & 6.21 & 6.38 \\
\hline Rural communes & 3.74 & 4.25 & 4.35 & 5.01 & 5.22 \\
\hline DOLNOŚLĄSKIE & 2.63 & 2.58 & 3.21 & 4.72 & 5.05 \\
\hline KUJAWSKO-POMORSKIE & 4.83 & 5.24 & 5.25 & 5.38 & 5.83 \\
\hline LUBELSKIE & 4.32 & 5.07 & 5.05 & 5.04 & 4.87 \\
\hline LUBUSKIE & 2.02 & 2.06 & 2.39 & 3.87 & 3.97 \\
\hline ŁÓDZKIE & 3.73 & 5.00 & 5.05 & 5.36 & 5.58 \\
\hline MAŁOPOLSKIE & 2.52 & 2.65 & 2.87 & 3.86 & 4.00 \\
\hline MAZOWIECKIE & 4.62 & 5.38 & 5.35 & 5.43 & 5.63 \\
\hline OPOLSKIE & 3.20 & 3.10 & 3.49 & 4.65 & 5.05 \\
\hline PODKARPACKIE & 3.43 & 3.45 & 3.56 & 4.88 & 5.56 \\
\hline PODLASKIE & 3.06 & 3.88 & 4.10 & 4.13 & 4.57 \\
\hline POMORSKIE & 3.68 & 3.87 & 4.36 & 5.67 & 5.93 \\
\hline ŚLA̧SKIE & 3.08 & 3.19 & 3.59 & 5.41 & 5.27 \\
\hline ŚWIĘTOKRZYSKIE & 5.41 & 6.56 & 6.56 & 7.41 & 7.25 \\
\hline WARMIŃSKO-MAZURSKIE & 4.57 & 5.06 & 4.40 & 4.40 & 4.74 \\
\hline WIELKOPOLSKIE & 4.20 & 5.32 & 5.08 & 5.13 & 5.21 \\
\hline ZACHODNIOPOMORSKIE & 3.26 & 3.99 & 4.02 & 4.13 & 4.60 \\
\hline
\end{tabular}

\begin{tabular}{c}
$\begin{array}{c}\text { Urban areas, } \\
\text { new provinces in Poland }\end{array}$ \\
$\begin{array}{c}\text { Rural areas, } \\
\text { new provinces in Poland }\end{array}$ \\
\hline
\end{tabular}

Figure 1. Distribution of the average morbidity indicator per 1,000 inhabitants in 2008-2012, divided into urban and rural areas

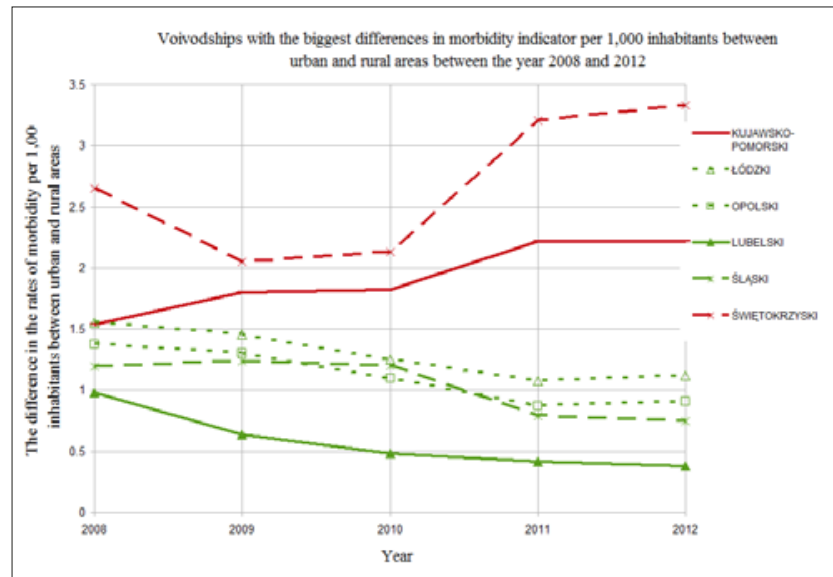

Figure 2. Value of the difference in the morbidity indicator dynamics per 1,000 inhabitants between $2008-2012$ in provinces

\section{DISCUSSION AND CONCLUSIONS}

The number of RA patients declared to the NFZ amounted to 173,844 in $2008,193,956$ in $2009,197,158$ in $2010,225,199$ in 2011, and 230,892 in 2012, which amounts to approx. $0.55-0.7 \%$ of the adult population. It should be assumed that this is the significant majority of sick people, since the study did not include only the ill who have never contacted a rheumatologist, or were treated only by general practitioners. So far, there are no epidemiological data for Poland, since the number of 300-400,000 which was used resulted from the application of general world statistics [18], which assumes that approx. $1 \%$ of the population suffers from RA $(0.5-2 \%)$ worldwide $[19,20]$. The values differ, sometimes significantly, depending on the year, assumed diagnostic criteria, and the age distribution of a studied group, etc. In 2002, Symmons et al. indicated that the frequency of occurrence of RA in 19911992 had decreased, compared to $1981-82$, by $31 \%$ for women and $19 \%$ for men, due to new diagnostic criteria introduced in 1987 [21]. It should be assumed that in the current study the diagnosis was made using the ACR criteria from 1987, whereas criteria from 2010 were used in 2011 and 2012 with some of the patients. Alamanos et al., when analysing the studies published in 1988-2005, assessed the frequency of occurrence of RA in Europe to be $0.2-0.85 \%$ [22]. Based on these data, Kobalt and Kasteng assumed that $0.45 \%$ of the current adult population suffers from RA (assuming the indicator calculated for Germany), which resulted in 131,546 patients, thus significantly less than in the presented study. The number of RA sufferers is increasing, which is probably a result of the increasing societal life expectancy. In the USA, the number of diagnosed RA sufferers in 2003 amounted to 45.8 million, in $2005-47.8$ million, and in the 2030 it is estimated that it will fluctuate around the level of 67 million people [23]. At the same time, the percentage of patients older than 65 will increase in 2030, compared to 2005 , from $12.9 \%$ to $20 \%$ [24]. The number of new occurrences amounts to, respectively: for men: $1-2$ cases per 10,000 persons annually, whereas for women: $2-4$ cases per 10,000 persons annually. The illness occurs 2-3 times more frequently among women than men [25]. Additionally, it is assumed that in the case of first degree relatives who suffer from RA, the risk of disease is $2-3$ times higher. The highest incidence is noted for patients between the ages of $30-50$. 
There are no data concerning these aspects of rheumatoid arthritis epidemiology in Poland, where patients from rural areas account for approx. 1/3rd of the total population of RA patients. The morbidity indicator in urban areas was more than twice as large as in rural areas. This is difficult to explain from the point of view of the RA pathogenesis which is not completely understood. The factors taken into account in this case are genetic predispositions (HLA-DR antigens), cigarette smoking, bacterial, mycobacterial, mycoplasma and viral infections. The genetic predispositions are probably not important here due to the racial homogeneity of the Polish population. Perhaps in rural areas contact with infectious factors is lower, but their role in the RA pathogenesis is unclear. The highest morbidity, both in urban and rural areas, is present in the Świętokrzyskie Province, which is not an industrialized area, which is why according to the authors the most probable explanation of the differences is worse access to a specialist physician, and the fact that the patients remain under the care of general practitioners; currently, it is not possible to obtain from them information about the type of treated patients, and additionally, in the current study it was assumed that the diagnosis had to be confirmed by a rheumatologist. Approximately $10 \%$ of the districts in Poland do not have a Rheumatology Clinic [26], and the lowest number of inhabitants per one employed rheumatologist is present in Świętokrzyskie Province, the highest in Lubuskie Province, and similarly, the number of inhabitants per one registered rheumatology clinic. In 2010, the most resources per one inhabitant NFZ assigned to the Świętokrzyskie Province (2.79 PLN), the least in Lubuskie Province (0.90 PLN). The distribution of morbidity in the provinces reflects the distribution of assigned resources [27]. This problem applies not only to Poland. Tavares et al. indicate that in only $21 \%$ of RA patients in the USA, appropriate therapy was implemented during the first 3 months, and in $41 \%$ within 6 months since the first symptoms of a disease appeared [28]. Too many patients with rheumatoid diseases remain solely under the care of general practitioners. It is estimated that only $27 \%$ of cases with RA diagnosed by a family practitioner are consulted by a rheumatologist in the first $2.5-3.5$ years of the disease [29]. The main reasons for this are:

- lack of typical symptoms of the disease;

- effectiveness of treatment provided by the GP clinic;

- lack of a Rheumatology Clinic near the patient's place of residence, or restricted access to the aforementioned clinic (excessive waiting time for a visit).

In the Polish population, women are ill 3.5 times more frequently than men. In the data reported worldwide, this relation is slightly lower and ranges from 1:2 - 1:3, but this may depend on many aspects of the studied population, e.g. - age. Symmons states a higher prevalence among men, if the group aged $45-64$ is taken into account. The advantage of the presented study compared to other publications is the inclusion of all the patients reported to the NFZ in Poland, and thus the limitations stated in other publications are immaterial.

When comparing morbidity in urban and rural areas in Poland with other countries, the current study concentrated on comparing the results in Poland and the UK, due to:

a) temporal closeness of the results of both studies;

b) comparable, close weather conditions;

c) similar organisation of the health services;

d) the population belonging to the same ethnic group.
Due to ethnic differences, the results of studies in China [30], Senegal [31], India [32] and Mexico [33] were not used for comparison. Studies in the Netherlands in $1988\left[^{\circ}\right]$ and in Spain in 2002 [34], have not been selected for comparison due to the large elapse of time. The study by Saag et al. published in 1998, unlike the presented analysis, concentrated on persons aged 65 and over [35]. Basu and Steven list as the factors responsible for the differentiation between urban and rural areas in the treatment of RA in the UK as: higher cost of living in rural areas and worse accessibility to medical services, and higher unemployment [11]. According to the authors, the two last factors are also present in Poland. At the same time, the studies in the UK also list as additional factors which increase health inequalities between urban and rural area inhabitants related to specialists' accessibility, the tendency to centralise specialised services combined with difficulties in retaining and recruiting rural doctors [11]. The Basu and Steven study demonstrates that in mountainous areas of Scotland, unlike in Poland, there is a small, negligible difference in the indicators of RA patients numbers per 1,000 inhabitants. The authors provide an indicator of 5.9 per 1,000 inhabitants: iIn rural and urban areas, respectively, 5.8 and 6.0 per 1,000 inhabitants [11]. Moreover, the study by Basu and Steven indicates that the inhabitants of rural areas with rheumatoid arthritis in the mountains of do not feel worse off concerning the treatment of their disease, compared to the inhabitants of urban areas [11]. This results from the fact that no significant difference was detected between the inhabitants of urban and rural areas concerning the RA treatment management, as stated by Basu and Steven:

Taking into account that there is no proof that the frequency of rheumatoid arthritis depends on the rural character of an area, similar rates in urban and rural areas described here do not support the suggestion of rural prejudice resulting in underestimated a certain number of patients [11].

The study by Bernatsky et al. in Canada indicates a differentiation in the health of inhabitants of the peripheries compared to urban areas, since the former are in a worse situation [10]. These authors conclude that referrals to a rheumatologist are delayed, in particular for older patients, those with a lower socio-economic status, and a long distance to specialised care.

Comparing the RA data in Poland with other EU and OECD countries, the possibility of using the national registers/ databases/IT systems containing RA patient information may be noted. The ability to use the IT sources of RA patient data facilitates the studies, and developing an RA patients' registry in Poland could increase the availability of correct RA therapy to patients, and increase the quality of care.

The problem when comparing Poland and the UK stems also from the difference in the definition of a rural area - a village. In the conducted study, the administrative/territorial division in force is used as the defining criterion. In the $\mathrm{UK}$, in addition to the number of inhabitants, an additional criterion is the distance which requires at least 30 minutes of car travel to a town with 10,000 or more inhabitants [10]. Other hindrances in the comparisons are:

a) structure of areas of residence (percentage of urban and rural population);

b) patients age structure; 
c) patients gender structure;

d) disease duration;

e) division of patient population according to the criterion of doctor registration in the UK vs. the declared place of residence in Poland.

The aforementioned issue concerning the results of the analyses in Poland and the UK, incomparable areas may be compared, e.g. in the mountainous areas of Scotland, $67 \%$ of RA patients live in rural areas, and only $33 \%$ in urban areas.

Contrary to the results of the Basu and Steven study concerning the mountainous areas of Scotland, in Poland there are differences in morbidity between urban and rural inhabitants. If it is assumed that the results obtained by Basu and Steven were to be applied to Poland (extrapolating the results of the presented study to Poland), the difference in morbidity between urban and rural inhabitants demonstrated undiagnosed, undetected morbidity. In order to eliminate the morbidity indicator differentiation, it is worthwhile monitoring this phenomenon. Basu and Steven emphasize, that:

It is not known, which element of the population or health care process leads to different results in rural population.

That is why the use of specific health care strategies for some diseases in case of rural population may turn out to be necessary [11].

The authors of the current study cannot explain the large differences in morbidity between individual provinces in Poland. Although it is considered that morbidity is higher in Northern Europe countries (0.66\%) than in Southern Europe $(0.45 \%)$, it is not known where the dividing line is drawn. This may be related to ethnicity-dependent genetic predispositions, lifestyle, climate, as well as with traditions and the possibility to diagnose the illness. Alamanos, however, considers that these differences do not reach statistical significance [22]. This rule may not be used in the material concerning Poland presented in the current study, since the distances between provinces are not large, and Poland is ethnically homogenous. Thus, the only explanation is the accessibility of rheumatologists $[36,28]$.

\section{CONCLUSIONS}

To summarise:

- in Poland, the number of RA sufferers is increasing, which is probably the result of increasing life expectancy

- in the Polish population, women fall ill 3.5 times more frequently than men;

- in Poland, differences in morbidity exist between urban and rural inhabitants;

- the highest morbidity, both in urban and rural areas, is present in the Świętokrzyskie Province, the most probable explanation of this fact is worse access to a rheumatologist: in this province there is the lowest number of inhabitants per one employed rheumatologist;

- developing an RA patients registry in Poland, epidemiological maps, and analytical applications with dashboards, could increase the availability, efficiency and quality of RA services.
- further research is needed to verify the association between age, gender of the patient and number of occurrences of $\mathrm{RA}$ in the provinces;

- the severity of illness, hospitalizations and clinical indicators must be taken into account in these studies; differences may also derive from undiagnosed cases of the disease.

\section{REFERENCES}

1. Filipowicz-Sosnowska A, Stanisławska-Biernat E, Zubrzycka-Sienkiewicz A, Reumatoidalne zapalenie stawów (Rheumatoid Arthritis). Reumatologia 2004; 42 (supl): 8-13.

2. Vandenbroucke JP, Hazevoet HM, Cats A. Survival and cause of death in rheumatoid arthritis: a 25 -year prospective follow-up. J. Rheumatol. 1984; 11(2): 158-161.

3. Mahold KP, et al. Very recent onset rheumatoid arthritis: clinical and serological patient characteristics associated with radiographic progression over the first years of disease. Rheumatology (Oxford), 2007;46(2): 342-9.

4. Arnett FC, Edworthy SM, Bloch D, et al. The American Rheumatism Association 1987 revised criteria for classification of rheumatoid arthritis. Arthritis Rheum. 1988; 31:315-324.

5. Aletaha D, Neogi T, Silman AJ, et al. 2010 rheumatoid arthritis classification criteria: an American College of Rheumatology/European League Against Rheumatism collaborative initiative. Ann Rheum Dis. 2010; 69: 1580-1588.

6. Green M., Marzo-Ortega H., McGonagle D. et al. Persistence of mild, early inflammatory arthritis: the importance of disease duration, rheumatoid factor and the shared epitope. Arthritis Rheum 1999; 42: 2184-2188.

7. Cooper NJ. Economic burden of rheumatoid arthritis: a systematic review. Rheumatology 2000; 39: 28-33.

8. Michaud K, et al. Direct Medical Costs and Their Predictors in Patients With Rheumatoid Arthritis: A Three-Year Study of 7,527 Patients. Arthritis and Rheumatism 2003; 48(10): p. 2750.

9. Cornelissen PGJ, Rasker JJ, Valkenburg HA. The arthritis sufferer and the community: a comparison of arthritis sufferers in rural and urban areas. Ann Rheumat Dis. 1988; 47: 150-156.

10. Bernatsky S, Feldman D, De Civita M, Haggerty J, Tousignant P, et al. Optimal care for rheumatoid arthritis: a focus group study. Clin Rheumatol. 2010: 645-57.

11. Basu N, Steven M. A Comparison of Rural and Urban Rheumatoid Arthritis Populations. Source: Scot Med J. 2009; 54: 7-9.

12. The Act of 27.08.2004 on healthcare services financed from public funds (Dz. U. of 2008, No. 164, item 1027 as amended).

13. Regulation of the Minister of Health of 11.01.2010 changing the regulation on guaranteed services within the scope of health programmes (Dz. U. of 2010, no. 05, item 29 as amended); Regulation of the Minister of Health of 02.03.2010 changing the regulation on guaranteed services within the scope of hospital treatment (Dz. U. of 2010, no. 30, item 157 as amended).

14. Regulation no. 36/2008/DGL by the NFZ President of 19.06.2008 on establishing the conditions of signing and performing of hospital treatment contracts for therapeutic health programmes; Regulation no. $65 / 2009 /$ DGL by the NFZ President of 19.06 .2008 on establishing the conditions of signing and performing of hospital treatment contracts for therapeutic health programmes; http://www.nfz-lodz.pl/index.php/ dlapacjentow/gdzie-si-leczy/2012

15. Porta M, A Dictionary of Epidemiology, Oxford University Press, Oxford, 2008, ISBN 978-0-19-531449-6

16. http://www.r-project.org/ (accessed 5.06.2013).

17. The Nomenclature of Territorial Units for Statistical Purposes (NTS) and National Official Register of Territorial Division of the Country - TERYT are available online: http://www.stat.gov.pl/bip/36_PLK_ HTML.htm

18. Terapeutyczne Programy Zdrowotne 2012 Leczenie reumatoidalnego zapalenia stawów (RZS) i młodzieńczego idiopatycznego zapalenia stawów (MIZS) o dużej i umiarkowanej aktywności choroby lekami modyfikującymi przebieg choroby (Therapeutic health programmes 2012: The treatment of rheumatoid arthritis (RA) and Juvenile Idiopathic Arthritis (JIA) with significant and moderate disease activity with drugs which modify the course of the disease). p. 4, online: http://www.nfzlodz.pl/attachments/3430_Leczenie\%20RZS\%20i\%20MIZS\%20o\%20 
du\%C5\%BCej\%20i\%20umiarkowanej\%20aktywno\%C5\%9Bci\%20 choroby\%20lekami\%20modyfikuj\%C4\%85cymi\%20przebieg\%20 choroby.pdf (accessed 5.07.2013).

19. Kokot F, et al. Choroby wewnętrzne (Internal diseases). Wydawnictwo Lekarskie PZWL. Warszawa 1997:647-653; Bulletin of the World Health Organization; V.81; No.9; 2003; p646.

20. Silman AJ, Hochberg MC. Epidemiology of the Rheumatic Diseases, Rheumatoid Arthritis, New York, Oxford Univerity Press; 2001: 31-71.

21. Symmons D, Turner G, Webb R, et al. The prevalence of rheumatoid arthritis in the United Kingdom: new estimates for a new century. Rheumatology (Oxford) 2002; 41(7): 793-800.

22. Alamanos Y, Voulgari PV, Drosos AA. Incidence and prevalence of rheumatoid arthritis, based on the 1987 American College of Rheumatology criteria: a systematic review. Semin Arthritis Rheum. 2006; 36(3): 182-8.

23. Hootman JM, Helmick CG. Projections of US prevalence of arthritis and associated activity limitations. Arthritis Rheum. 2006; 54(1): 226-9.

24. Centers for Disease Control and Prevention. Public health and aging: projected prevalence of selfreported arthritis or chronic joint symptoms among persons aged $>65$ years-United States, 2005-2030. MMWR Morbidity \& Mortality Weekly Report. 2003 May 30; 52(21): 489-91.

25. Abdel-Nasser A.m, Rasker J.J, Vaikenburg H.A, Epidemiological and clinical aspects relating to the variability of rheumatoid arthritis. Semin Arthritis and Rheum. 1997; 27(2): 123-140.

26. Drapała A, Grabowska Woźniak E, Gryglewicz J, et al. Stan opieki reumatologicznej w Polsce. Streszczenie raportu projektu badawczego (Condition of rheumatological care in Poland. Abstract of a study project report). Uczelnia Łazarskiego, Warszawa 2011 (in Polish).
27. Gryglewicz J. Świadczenia opieki zdrowotnej w zakresie reumatologii w $2010 \mathrm{r}$. (Providing of rheumatology health care services in 2010) Uczelnia Łazarskiego, Warszawa 2010.

28. Tavares R, Pope JE, Tremblay JL, et al., Time to diseasemodyfyingAntirheumatic Drug Treatment (...). J Rheumatol. 2012; 39(11): 2008-2096.

29. Feldman DE, Bernatsky S, Haggerty J, et al. Delay in consultation with specialists (..). Arthritis Rheum. 2007; 57(8): 1419-1425.

30. Xiang Yao-Jun, Dai Sheng-Ming. Prevalence of rheumatic diseases and disability in China. Rheumatol Int. 2009; 29(5): 481-490.

31. Lekpa F, Ndongo S, Tiendrebeogo J, Ndao A, Daher A, et al. Rheumatoid arthritis in Senegal: a comparison between patients coming from rural and urban areas, in an urban tertiary health care center in Senegal. Clin Rheumatol. 2012: 1617-20.

32. Patel M. An Epidemiological survey of arthritis in the population of North Gujarat, India. Int J Pharm Sci Res. 2011; 2(2): 325-330.

33. Rodriguez-Amado J, Pelaez-Ballestas I, Helena Sanin L, et al. Epidemiology of Rheumatic Diseases. A Community-Based Study in Urban and Rural Populations in the State of Nuevo Leon, Mexico. J Rheumatol. 2011; 38 (Supplement: 86): 9-14.

34. Carmona L, Villaverde V, Hernandez-Garcia C, Ballina J, Gabriel R, et al. The prevalence of rheumatoid arthritis in the general population of Spain. Rheumatol. 2002; 41: 88.

35. Saag KG, Doebbeling BN, Rohrer JE, et al. Arthritis health service utilization among the elderly: The role of urban-rural residence and other utilization factors. Arthritis Care Res. 1998; 11(3): 177-185.

36. Kobelt G, Kasteng F. Access to innovative treatments in rheumatoid arthritis in Europe. A report prepared for the European Federation of Pharmaceutical Industry Associations (EFPIA). Lund University (Sweden) Oct. 2009). 